\title{
Interpretation of the "Mediocre" Hero in the Novels by Ivan Goncharov and Leo Tolstoy
}

\author{
Ekaterina I. Shevchugova* \\ Siberian Federal University \\ 79 Svobodny, Krasnoyarsk, 660041, Russia
}

Received 10.01.2017, received in revised form 13.03.2018, accepted 16.03.2018

The article investigates the identification and characterization of the "mediocre" hero in the novel trilogy by Ivan Goncharov and the novel-epopee 'War and Peace' by Leo Tolstoy. The research method is typological. The theoretical basis of the research includes the investigations by V.Markovich and A.Davydov. The article describes similar typologies of characters in Goncharov's and Tolstoy's novels. The terminal points of typology are presented by the impersonal type of characters (which have no outstanding features: Alekseev, Ayanov, Karataev) and the excessive type of characters (they have one or more of outstanding features; they are Raysky, Natasha, Andrey Bolkonsky). In the field of mediation there is the "mediocre" hero: a special type of personality characterized by evenness, calmness, moderate expression of emotions, restraint actions. But the "mediocre" hero in Goncharov's novels is able to overcome the boundaries of his type occasionally going beyond the usual level of feeling (Stoltz and Olga Ilyinskaya, Oblomov, Tushyn), and the "mediocre" hero in Tolstoy's works is not able to do it (Nikolai Rostov).

Keywords: Ivan Goncharov, Leo Tolstoy, mediation, typology of characters, “mediocre” hero.

DOI: 10.17516/1997-1370-0239.

Research area: philology.

\section{Introduction}

The features of the heroes of literary works sometimes include such definitions as colourless, ordinary, inexpressive, etc. Thus, V.G. Belinsky considered Petrusha Grinyov "an insignificant, colourless character" (Belinskii, 1955: 577). As a rule, in such cases, critics and literary scholars have in mind that the author failured in creating the hero. Although it is difficult to doubt both the creative genius of Pushkin, and Belinsky's critically correct view. Though an attentive look at the heroes given such definitions, shows: behind the character accused to be ordinary and mediocre, there is not a typical person as a result of the artistic weakness of the author, but the "mediocre" hero as a result of conscious creative search.

The "mediocre" culture was conceptually expressed by A.P. Davydov in his monograph of 2001 "'Spiritual thirst: Alexander Pushkin and the formation of the "mediocre" culture in Russia". The researcher defines the concept of "mediocre" culture as a search for new ideas in the area between established stereotypes. At the

(C) Siberian Federal University. All rights reserved

* Corresponding author E-mail address: e.pinzhenina@gmail.com 
same time, "mediocre" is peculiar to European culture, and therefore is understood in Western science: there it is studied as a cultural standard, which constantly faces the threat of blurring. The same "mediocre" nature of culture is not typical for Russian culture, and therefore, is little understood in the national science (Davydov, 2001: 14, 15). Chekov's words about God come to mind that "the Russian man is not interested in the middle", and also the position of the philosopher B.P.Vysheslavtsev, who argued that the Russian people do not have a sense of proportion and middle, which results in the chaos of the unconscious or even the very programmed miniature of Alexei Tolstoy in 1854:

If you love, then love without thinking, If you threaten, then do it without joking, If you curse, then do it with anger,

If you speak, then do it straight from the shoulder!

If you argue, then do it bravely,

If you punish, then do it for a reason,

If you forgive, then do it heartily,

If there's a feast, then let it be lavish!

A.P.Davydov believes that mediation, that is, the desire for the development of the middle in Russian culture began with Pushkin, for him the search for the "middle", i.e. of the third sense as a means of overcoming contradictions was the basic principle of thinking, and his creativity marked the beginning of the "mediocre" culture in Russia and, consequently, through him, the creativity of Lermontov, Gogol, Goncharov and Chekhov should be understood (Davydov, 2001: 19-20, 26), and the scientist does this in the above monograph. However, Davydov's research is still sociocultural, philosophical and requires clarification from the standpoint of literary criticism. At the same time, mediation is not gray creativity, averaged level of reflection. This is a way out into a new semantic space that forms new meanings (Davydov, 2001: 40).

When referred to literature, V.M. Markovich proposed the concept of the "mediocre" hero in the novels of I.S. Turgenev much earlier. In the chapter "Levels of Humanity" he builds the typology of Turgenev's heroes on the basis of the type of relationship with the surrounding world. The researcher identifies four types of characters: the first type is the archaic people of the "previous epoch", all their consciousness and all life are subordinated to ready standards offered by their environment, set by tradition, they are firmly rooted in their social environment, their being is harmonious, comfortable though limited (Markovich, 1975: 152-155). The second category of characters is represented by egoists or "inferior" of modern types. They are uncomfortable within their social environment, but they do not go beyond it. They strive for practical success, compensating for their own inferiority, they are able to adapt to the norms of the environment. For such characters, a rush beyond the limits of everyday standards is possible, but it quickly fades away or it is largely outwardly conditioned, mechanical (Markovich, 1975: 155-158). The third group of characters in Markovich's typology is most important for our research - characters with elements of spirituality, people of the "middle" position or people of the "golden mean". According to the researcher, these are Lezhnev and Volyntsev, Basistov and Mikhalevich, Bersenev and Shubin, Pavel, Nikolay and Arkady Kirsanovs. They are distinguished by more dignified prominent features than the previous group, but these features are ready, taken from the outside. If they deviate from the standard, they do not go far, remaining at a safe distance from it. For such characters, moral search is possible, but within reasonable and quite restricted limits, all their merits are apparently moderate. They do not sacrifice, they do not take risks, that is why 
they do not fall into tragic situations, the range of their ideals is rather narrow. The characters of the "golden mean" are to some extent selfish, but they are satisfied with what is possible and available. It is noteworthy that only for the characters of this group it is possible to achieve happiness (Markovich, 1975: 158-166). "The ability to love and be happy is the value of the people ready to be reconciled to the ordinary destiny or even not to look for another" (Markovich, 1975: 184). Finally, the fourth group of characters - heroes in the full sense of the word - are "supreme", special people. They create standards for themselves, then they spread them in life, therefore they can be called epochal heroes. Ordinary human needs and ideal aspirations collide in them. The impossibility of resolving this conflict, above all, is the tragedy of the position of such heroes (Markovich, 1975: 166).

\section{Theoretical Framework and Methods}

In our study we will rely on Davydov's concept and its main provisions, also bearing in mind the typological method used by Markovich. It should be clarified that the notion of the "mediocre" culture was introduced by N.A. Berdyaev, although it is not certain yet. This is "an innovation in culture overcoming the limitations of previously established stereotypes" (Davydov, 2001: 14, 19). Moreover, the philosophical foundations of our study are taken from the works of K. Levi-Strauss, M.M. Bakhtin, Yu.M.Lotman, A. Akhiezer, where the middle is often defined as the third alternative meaning. At the same time, the ancient source of reasoning is the idea of the "golden mean" of Horace.

\section{Statement of the Problem}

We believe that the "mediocre" hero of different authors will have different features while preserving a certain set of common features. It is necessary to determine how often the "mediocre" character is typical for a particular writer (for example, for Goncharov it is typical and frequently met, for Dostoevsky it is not typical at all'); for Gogol and Tolstoy it is a rare phenomenon. It is important to understand how the middle-type hero is ideologically loaded (for example, in Gogol's works it is the main character, in Tolstoy's these are peripheral characters). In the given work, these issues are resolved in terms of the novel trilogy by Goncharov and the novelepic by Tolstoy.

\section{Discussion}

The "mediocre" hero in the novel trilogy by Ivan Goncharov

A special significance of the "mediocre" hero in Goncharov's creative works can be already noticed on the example of peripheral images. These are the "first students" who outmatched Raisky in school and who were always set as an example for him, as they were equally diligent in all subjects, without any preference, and afterwards they did any work satisfactorily and evenly, without any enthusiasm (Goncharov, 2004: 86-87). Echoing this characteristic, Oblomov's words characterize typical representatives of the society, which "rush in all directions without any destination in mind", here the hero sees emptiness that frightens him (Goncharov, 1998: 175). Positive Pyotr Aduev, Stoltz and Tushin are in many respects similar to these "first students" who, in fact, are exactly "mediocre" people. Oblomov and Raisky, on the contrary, are delimited from them, they are extraordinary characters, "excessive" (conditionally speaking, Oblomov has an excessively developed soul, and Raisky has imagination). The statement of Boris Pavlovich is quite remarkable in this regard: "It is only the digression from order, from standard, from your boring rules, which brings happiness ...” (Goncharov, 2004: 25). 
A typical "mediocre" and the first hero in Goncharov's novel world is Pyotr Ivanych Aduev. Proportion, correctness, standard: these are the accents in his portrait and character (Goncharov, 1997: 193-194). The self-description of Pyotr Ivanych is similar: we observe the same as in the case with the "first students", even and similar attitude to everything, reluctance or incapacity for showing enthusiasm, manifestation of a strong, excessive feeling, even laughter as something excessive is logically untypical for the hero. The author creates the impression that Uncle Aduev is a man as if without character, while Alexander is a personified extreme. It is important to note that when working on the editions of the novel "A Common Story", it was the image of Pyotr Aduev which had the most significant number of changes made by Goncharov concerning the removal of emotions in the cues of Uncle Aduev.

In the end of the novel, the method of Pyotr Ivanych reveals its perniciousness. It is noteworthy that having understood the error and inferiority of his methods, Pyotr Ivanych thinks and calculates, but understands that no medicine would help. Even in such a situation, he appears to be absolutely incapable of overcoming the limits of expressing his feelings that he has established. The only thing that the hero decides to do is to passionately kiss the hand of his wife (Goncharov, 1997: 462). In "A Common Story" longing towards the stability, the standard, the "mediocrity" turned out to be stronger than a person's need to accomplish something that goes beyond the limits of inherited experience, to break the boundaries of being. The "mediocre" hero here is described rather negatively and the main accusation is the ruined life of Lizaveta Alexandrovna.

As for Andrey Ivanovich Stoltz, the researchers seem to never have any doubts: it is a typical "mediocre" hero. In the major article by
A.V.Druzhinin (1859) "Oblomov. Novel by Ivan Goncharov", the hero is called an ordinary person and does not try to be extraordinary (Druzhinin, 1983: 305). V.R. Ivanov-Razumnik (1907) defines Stoltz as a man neither gentle nor hearty, smooth and average (Roman 'Oblomov' v russkoi kritike, 1991: 268). Critic under the pseudonym Kolobok without any indulgence calls it a surrogate of the 'real man' (Pokrovskii, 1907: 192), and N.D. Akhsharumov (1859) "golden mediocrity" (Roman "Oblomov" v russkoi kritike, 1991: 162, 165). The tradition of understanding the image of Stoltz by the critics of Goncharov's time is continued by modern researchers, noting that the hero dislikes any example of overflowing life (Faustov, 1990: 13), he is devoid of any extremes and is committed to the "standard" of life (Nedzvetskii, 1992: 38, 43).

Let us turn to the author's description of the hero. Is he a "mediocre" hero in the pure form, as it was the case with Pyotr, and then Alexander Aduevs? On the one hand, the hero's commonness originates in the path chosen for him by his German father, in the description of which there are two key lexemes: cold-blooded and straightforward. Thanks to this, Stoltz has got a "simple, that is, a straight, real understanding of life ..." (Goncharov, 1998: 162). And in the description of his character an equally important place is taken by the lexeme straightforwardly/ stubbornly. On the other hand, some German standard is overcome by the influence of his mother: "Hertz's variance, dreams and mother's stories, a gallery and a boudoir in the prince's castle will turn the narrow German track into such a broad road that neither his grandfather, nor his father, nor himself have ever dreamt about" (Goncharov, 1998: 158). The typology of mother's images in Goncharov's novels is described in the article by E.I. Shevchugova "The Image of the Mother in the Novel Trilogy by I.A. Goncharov: Typology and Functions" (2013). 
Andrey Stoltz is a "mediocre" hero, which is determined by the features already singled out in the analysis of the image of Pyotr Aduev: restraint, lack of impulses, normality, evenness of actions, feelings and life in general. The main feature of the "mediocre" hero is his fundamental inability to transgress the boundaries of ordinary, normal life, to make a choice in favour of the new, unexplored. The stability of the "limiters" in the character of Stoltz is really strong. I.A. Goncharov repeatedly speaks of the inability of the hero to get carried away: "Even in the midst of infatuation, he kept his feet and sufficient inner strength to tear himself away in the event of extremity and be free". He also felt the ground under his feet and enough strength in himself to rush and be free in case of extreme. $\mathrm{He}$ was not blinded by beauty and so did not forget or demean his dignity as a man, was not a slave, and did not "lie at the feet" of beauties, although he did not experience impassioned delights, either" (Goncharov, 1998: 163). In "Oblomov" there is an episode where Stoltz's closeness to the "first students" is undeniable. It is about the father's advice to choose any "career": "to serve, to trade, at least to compose, perhaps ...". "Yes, I'll see if it's possible to succeed in all, said Andrey "(Goncharov, 1998: 159). With respect to the "first students" it sounded like "they were doing satisfactorily in all subjects".

Even though such a "standard", "middletype" hero is very determined, he is not able to act when this action requires overcoming the boundaries of the norms that he has accepted: in a situation where courage and passion are necessary. Finally, the author emphasizes the absence of any excessive features in the character of Stoltz. It is important to note that in the manuscript, early editions of the novel "Oblomov", Stoltz was more expressive in demonstrating his emotions, he appeared to be a much more passionate person. In the final version of the novel Goncharov makes him more restrained. Let us, for example, recall on the episode from the final part of the novel, when Andrey Ivanovich gets to know that Oblomov lives in extreme poverty and that he was swindled by Taranteyev and Mukhoyarov and even then, the hero stays decent, quiet and smooth in perception of life events.

Therefore, both P.I. Aduev, and A.I.Stoltz from edition to edition are more and more approaching the type of the "mediocre" hero, becoming less expressive, losing excessive features in character. And one of the most positive characters in Goncharov's novel world turns out to be little different from the "first students" described above, those who would be never able to overcome the usual, trivial level of life and feeling, get carried away by something special. However, Stoltz demonstrates an episodic disintegration of the "mediocre" hero, and this is manifested in his relationship with Olga Ilyinskaya.

Olga Ilyinskaya is an image that evokes the most diverse responses of criticism. Goncharov loved this character, which is repeatedly proved by epistolary testimonies. Researchers of the late time adhere to one of the points of view in relation to the nature of the character: 1) Olga as a person of the "standard" (Kadmin, 1913: 48; Nedzvetskii, 1992: 42); 2) Olga as a person overcoming the "standard" (Krasnoshchekova, 1997: 294, 295; Faustov, 1990: 15). Let us try to understand this paradigm of research opinions.

In our opinion, Olga Ilyinskaya is a female version of the "mediocre" hero. The writer immediately destroys the reader's expectations: "She was very happy to see Stoltz; although her eyes did not light up, her cheeks did not blush, but a smooth, even light spread over her face and a smile appeared" (Goncharov, 1998: 189). Further, the key word-companion, marking the image of Olga, is "simplicity". And in the portrait of the character, the writer emphasizes 
moderation and evenness. Probably, like Stoltz's directness and equality came from his father's upbringing, Olga inherited this feature from her aunt, which is a typical "mediocre" female image. Goncharov writes about this frankly, lexically emphasizing her narrow-mindedness: "... she seems to have a strict line in her head, beyond which her mind has never passed" (Goncharov, 1998: 220). The writer insists that the impulses are fundamentally not typical for her, typologically this description is similar to the entire portrait of the "mediocre" hero Stoltz. The following coincidence indicates the validity of comparing Olga and her aunt: the aunt treats the baron "as others: favourably, with kindness, but equally smoothly and calmly" (Goncharov, 1998: 220). It seems that it is no coincidence that Olga's behaviour shows the same features. Her love for Oblomov is similarly smooth and even. Ilya Ilyich feels this, and as if does not trust, does not recognize this love as real: "She loves like she stitches embroidery: the pattern goes quietly, lazily, she lazily unfolds it, admires it, and then she will put it away and forget. Yes, this is only a preparation for love, an experience, and he is the subject who first turned out, a bit tolerable, for experience, on the occasion ..." (Goncharov, 1998: 249). Oblomov tries to disturb Olga's smooth, calm feeling, at least with a letter, to lead her beyond the limits of her usual being. The researchers judge the success of this "checking" differently, speaking about the insincerity of Olga, her set behaviour (Bulanov, 1992: 50) or do not trust her calmness (Prutskov, 1962: 8). Nevertheless, it is indisputable that Ilya Ilyich needs a special level of feeling that goes beyond the ordinary, trivial, if not higher, then at least not less than Olga's, which is so often called free from conventions and prejudice. Analysis of the image of the character shows the eligibility of attributing Ilinskaya to a "mediocre" type of characters.
Ilya Ilyich Oblomov is a hero, still unequivocally not defined by literary criticism. V.N.Krivolapov rightly calls him perhaps the most mysterious and inexplicable character in Russian literature, moreover, the character that is not completely clear to Goncharov himself (Krivolapov, 1994: 27, 29). In the considered paradigm of "mediocre" and excessive heroes, Oblomov's position is noteworthy, since the traits of both types coexist in him. He directly declares to Zakhar: "To move to a new apartment, to the village, by myself! What desperate measures you are offering! <..> Why not avoid extremes and hold on to the middle ..." (Goncharov, 1998: 49). The hero already in his childhood lacks the desire to overcome something limited by the programme, the prescription. Goncharov sums up Oblomov's studies: "The day when he listened to the last lecture was the limit of his studies. The head of the institution signed his certificate, as the teacher used to scratch with his nail in the book, he draw a line, beyond which our hero did not consider necessary to extend his scientific aspirations" (Goncharov, 1998: 63). (Goncharov, 1998: 63). The author emphasizes the absence of an internal message to the movement in the hero. Such a lack of enthusiasm is repeated in the description of Stoltz and Olga's aunt, Marya Mikhailovna. This feature is even more vividly expressed in the handwritten editions of the novel "Oblomov". Let us quote a completely colourful episode, which was cut out of the final version of the novel. It clearly demonstrates Oblomov's inability to retreat from his programme, thus confirming our point of view on him as a "mediocre" hero: "He learned to start the mazurka and quadrille from the stove, and he danced regularly in society if he had to stand by the stove, but if he had to start from the window, he will certainly confuse everything" (Goncharov, 2003: 111). The hero himself claims that he is unable to overcome the boundaries of the habitual way of life: "It's like 
suddenly going up in the sky and fly like birds!" (Goncharov, 2003: 213).

Zakhar is a satellite image of the main character, which S.Mashinsky calls microOblomov (Mashinskii, 1972: 39). The leitmotif of reflection of the same qualities in the master and the servant is observed throughout the novel, including the inability to transgress the boundaries of habitual behaviour. This applies, for example, to the list of household duties of the servant: "Zakhar decided on a certain range of activities which he had never gone beyond voluntarily" (Goncharov, 1998: 70).

As Stoltz has never been at the feet of the beauties, so has not been Oblomov, though for another reason. The hero dreams of meeting a woman who knows no impulsion, although this is what he lacks in the feeling of Olga Ilyinskaya. This, of course, indicates that Oblomov is a special "mediocre" hero. Ilya Ilyich adequately imagines a future family, saying that passion should be strangled and drowned in marriage (Goncharov, 1998: 204). Based on this and similar statements of the hero, the researchers conclude that breaking up with Olga Ilyinskaya is due to Ilya Ilyich's inability to "endure passion" (Kotel'nikov, 1987: 29). However, the hero was destined to experience going beyond the measured, sleepy existence in the history of love for Olga Ilyinskaya. The hero is still capable of passion, excessive sensations and emotions, overcoming the "programme" of his own life.

In the novel "The Precipice" the starting point for the "mediocre" heroes is Sofya Nikolaevna Belovodova - a character with a practically "zero" emotional level. She, both in education and in the environment, is even deprived of the opportunity to go beyond the boundaries defined by her social status. The portrait and spatial organization of the narration about her supports this characteristic. In the light of our concept, she is a typical "mediocre" heroine, unable to overcome the boundaries of the limited domestic level of existence. The space in the house of the Pakhotins is fundamentally normalized and closed, here any deviation from the institutions and rules is pursued. The nature of Belovodova precisely corresponds to her education and environment. Raisky feels it, "he wanted to find just a woman in her, to observe and determine what lies beneath this even, immobile shell of beauty shining smoothly and equally, never throwing a fast, thirsty, fiery or, at least, boring, tired eye at anything, having never uttered an impatient, reckless or impulsive word? <...> She seems not to have heard that there are passion, worries, a wild play of events and feelings leading to curses, erasing this shining smoothness from one's face" (Goncharov, 2004: 20-21). This passage lexically echoes with the description of Olga Ilyinskaya, which is important not so much to clarify the image of Belovodova, since there are few really requiring comments. Comparison is unflattering precisely with regard to Olga Sergeevna, since lexical correlation brings her image closer to the limited character of Sofya, confirming the nonrandomness of our attribution of Ilinskaya to the "mediocre" heroine.

The last among the "mediocre" characters is Ivan Ivanovich Tushin. The writer himself calls him a normal person (Goncharov, 1980: 135). Lifelong criticism and modern researchers insist that the hero, like the "positive" Stoltz was characterless, implausible, both of them are characterized by directness and integrity. Unlike Oblomov and Raisky, positive antipode heroes are distinguished by completeness. It also makes them in a certain sense limited, which allowed us to define their character as "mediocre". Goncharov emphasizes that both in Tushin's character and appearance, there are no features out of the ordinary: "He had such a mind that can be given both to a delicate person and to a peasant, a mind that without being spent on 
luxury, directly becomes an everyday necessity" (Goncharov, 2004: 455-456). In accordance with the character and position in society, such a person cannot be outstanding: "Such people are not visible in the crowd, they are rarely in the foreground. Sharp and subtle minds, with a lively word often overshadow such personalities ..." (Goncharov, 2004: 456). Such a "mediocre" hero is "entrusted" the salvation of the heroine who broke the limits of the "standard" - Vera: Tushin was supposed to become, according to Goncharov's plan, a companion and guide of the return of Vera to the space of her grandmother's standards. However, despite Tushin's "positiveness", among the researchers there is a tradition of mistrust in the possible joint happiness of Vera and Tushin (Prutskov, 1962: 8; Nedzvetskii, 1992: 58).

Apparently, the writer was thinking about the problem of a positive person, about the lack of life and enthusiasm in Stoltz, so he tried to put in Tushin's image the ability and even the need to sometimes get out of the circle of habitual affairs and worries, to feel the special intensity and fullness of being: he used to go hunting, fishing, enjoyed visiting single neighbours, sometimes gave receptions, and liked to have fun occasionally, that is, to go horse riding with friends to visit a distant neighbour and to spend three days there, and then come back with them or go to the city, to shock the silence of the sleepy city with such a huge feast that everything will falter in the city $<\ldots>$ More than once after such feasts Tushin would spend three or more weeks with his hand tied, with an injured shoulder, and sometimes with a forehead scraped by bear's paw. But he liked this life, and he would not abandon it" (Goncharov, 2004: 454). It seems that this attempt to bring Tushin closer to the "pole of excessiveness" seems somewhat mechanical. Nevertheless, it seems that Tushin as a "positive" hero stepped a little farther than Stoltz, there is more life in him, at least he is familiar with the hobby, the feeling of fullness of being, which in part brings him closer to Raisky. Perhaps this indicates that in Goncharov's final novel the image of the positive hero gets the traits of Goncharov's dramatic characters with their attempts to break beyond the boundaries of the "middle", which, actually Olga Ilyinskaya, Oblomov, Vera and Raisky are driven by. Although the manifestations of Tushin's "unrest" are still external, and therefore somewhat arbitrary, not able to witness the true breadth of nature. The "mediocre" hero tries to break the rhythm of existence, but only occasionally (Stoltz, Olga).

Goncharov has characters of all three types: impersonal (Alekseev, Ayanov), heroically excessive (Volokhov, Raisky, Vera) and "middletype", which are inhomogeneous within themselves. These "middle-type" characters are those close to the "impersonal" ones, originally not very remarkable, or brought up by such people (Pyotr Aduev, Lizaveta Aleksandrovna, Olga's aunt, first students, Sofya Belovodova), and the "middle-type" characters, gravitating to another pole, to the pole of "excessiveness"; these are heroes who try or are compelled by circumstances or the logic of their own nature to overcome the "middle" in themselves (Stoltz, Olga, Oblomov, Tushin).

\section{The "mediocre" hero in the novel-epopee}

\section{by Leo Tolstoy "War and Peace"}

The second type of the "mediocre" hero, as an example of the ordinary, is represented in the novel-epopee "War and Peace" (1869) by Leo Tolstoy: here there appear heroes that are conditionally "excessive", conditionally and in different ways "impersonal" and heroes that are "ordinary", which in special circumstances though reveal their depth and significance. But none of these types is similar to the Goncharov's "mediocre" heroes or heroes of the "golden mean". 
Thus, Tolstoy's most important characters are characterized by lack of measure, vividness in living and expressing emotions. This is typical though in different ways for Andrey Bolkonsky, Pierre Bezukhov and, especially, first and foremost, Natasha. Beginning with her first appearance in the novel ("she accidentally got so far"; "She fell on her mother and burst into such loud and ringing laughter that everyone else, even the prim guest, laughed involuntarily", "unable to control herself any longer, she jumped up and ran from the room as fast as her nimble little legs would carry her". They say "Gunpowder!" about her (Tolstoi, 1961: 54-56, 59) Of course, Boris will not become Natasha's companion: his steps are "not quiet, not fast, decent", a smile is always pleasant, and speech is calm (Tolstoi, 1961: 61, 74).

It is noteworthy to compare Natasha with Vera, in which everything is good and right, but nobody sincerely loves her, she is not interesting to either the heroes or the author, she then converges with the equally smooth and uninteresting Berg. Natasha will openly talk about this (having realized this when she was 13): "You've never loved anyone; you have no heart". Vera has the same opinion about herself: "Nothing can be ever bad in my actions" (Tolstoi, 1961: 64). Though Natasha's actions can: she will both be bad, and do evil, she will go through all author's moral checks. There is nothing to test in Vera, therefore it is not interesting.

Natasha's dance after the hunt, getting ready for travelling away from Moscow, of course, the decision to release the carts for the wounded all these actions manifest courage, excitement, the fullness of nature, the ability to resign to the moment. These features have family roots - in the character of the old count, Ilya Rostov. Let us recall how different is Rostov's reception in Moscow from the Scherer's salon in St. Petersburg: Count Rostov dances Daniel Cooper with Marya Dmitrievna: "In the intervals of the dance the count, breathing deeply, waved and shouted to the musicians to play faster. Faster, faster and faster; lightly, more lightly and yet more lightly whirled the count, flying round Marya Dmmitrievna, now on his toes, now on his heels; $<\ldots>$ he executed the final pas $<\ldots>$ amid a thunder of applause and laughter led by Natasha", which, by the way, shouted to look at Papa "to the whole company $<_{\text {... }}>$ bending her curly head to her knees and making the whole room ring with her laughter" (Tolstoi, 1961: 94, 95). The count himself speaks of Natasha: "Gunpowder! <...> She is like me!" (Tolstoi, 1961: 59).

It is noteworthy that Natasha is especially attractive at such moments, the manifestations of vital excitement, the strength in all its completeness, both the author and the hero who turned out to be next to her, admire her. Prince Andrew feels this fullness of life in Natasha at night in Otradnoye. This is what he recalls before the fateful battle of Borodino: her emotional, incoherent story of how she lost her way in the forest: "I understood her <..> I not only understood her, but it was just that inner, spiritual force, that sincerity, that frankness of soul - that very soul of hers that I loved..." (Tolstoi, 1962a: 241). Natasha makes others feel special (provokes the sudden marriage proposal from Denisov, Prince Andrew).

The irritation and passion of Andrew first become apparent in his address to Pierre after he frankly demonstrated boredom in Scherer's salon: "His dry face was quivering with nervous excitement in every muscle; his eyes, which had seemed lusterless and lifeless, now gleamed with a full, vivid light. It seemed that the more lifeless he was at ordinary times, the more energetic he became at such moments of morbid irritability" (Tolstoi, 1961: 41). He wants to have his own Toulon in order to outmatch others, to become special: "it had come-the Toulon-that would lift 
him forever from out of the ranks of unknown officers, and open the first path to glory for him!" (Tolstoi, 1961: 219). As is known, Tolstoy considered this way erroneous, and made Andrew understand this as well. Natasha's excessiveness, peculiarity is a characteristic of nature. It should be such, because one cannot become special arbitrarily. Otherwise, Pierre and Princess Marya are "excessive" - with their extraordinary spiritual work, spiritual depth superior to the average person.

The second feature of Tolstoy's attitude to mediocrity is that the appearance of evenness and calmness in the characters is alarming, associated with a disease or another extraordinary event or a special condition. Thus, Natasha's behaviour after Prince Andrew's proposal arouse mistrust in sensitive Nikolai, the mother-countess, or come to mind the frightening evenness of Prince Andrew signifying the transition from life to death, the awakening to death (Tolstoi, 1963: 67), Princess Marya is struck by his even and alien voice, when he meets her, asks about Nikolai: "His words, his tone, especially his stare - a cold, almost hostile stare - gave a feeling of detachment from the living that was frightening for the living person" (Tolstoi, 1963: 67, 68).

The third peculiarity of Tolstoy's interpretation of the "mediocre" hero lies in the fact that they are quite rare in general in the novel world, they are all secondary or episodic, and the author does not focus on them. Thus, Sonya remains strictly within the boundaries of the type, she is directly opposed to the excessive Natasha: "And how can Sonya so evenly, calmly love Nikolai and wait so long and patiently!" (Tolstoi, 1962a: 356). Only once something special can be noticed in Sonya - in the episode of the trip of mummers, here, probably, Natasha and in part Nikolai "charge" the atmosphere and at the same time, "even" Sonya. For more details about Sonya's "insignificance", see Anna Dvigubski
(2016) “Sonja’s Lie: Tolstoj’s Marginal Woman Takes on a Career".

It seems that mediocre nature is untypical for Tolstoy's heroes, and evenness, normality and commonness are rather negative features from the author's point of view. Such characters are not particularly interesting to the writer, although such characters are quite nice: for example, Desall, the teacher of Nikolai: "a limited-intelligent, educated, virtuous and pedantic educator" (Tolstoi, 1962b: 43). But limited heroes or those seeming such sometimes reveal themselves in fullness and significance: for example, Konovnitsyn and Dokhturov enjoyed the reputation of people of very limited abilities and information $<\ldots>$ but always were there where it was most difficult (Tolstoi, 1963: 128). The character of Kutuzov is neither episodic, nor the main character; he seemed to be the simplest and most ordinary person and spoke the simplest and most ordinary things (Tolstoi, 1963: 210), however, he becomes the savior of the Fatherland. It turns out that according to Tolstoy, the way out of the habitual life is occasionally possible in connection with the demand of the historical moment. It turns out that the "mediocre" hero has the potential, features that allow him to overcome the limitations.

The only "mediocre" hero of the important characters in "War and Peace" is Nikolai Rostov. $\mathrm{He}$ is less bright than Natasha and his father; however, family features appear in him as well: enthusiasm in house holding, incontinence (Tolstoi, 1963: 287-288). This character clearly pretends to be called the "mediocre" one: "He had that common sense of mediocrity that showed him what was due" (Tolstoi, 1962a: 266). Therefore, Nikolai, on the one hand, is not Tolstoy's favorite hero, on the other hand he is worthy of Marya. It is his relationship with Princess Marya where his impulses and ability to go beyond the usual 
level of feeling are manifested: first he "blabs out" his sympathy for the princess to his aunt (Tolstoi 1963: 26), thus starting the mechanism of making a proposal, the second time it is his frank conversation with the princess, which resulted in their marriage. That is, from the point of view of "mediocrity" the hero is contradictory (on the one hand, Tolstoy calls him mediocre, on the other, from time to time endows him with impetuosity: "Nikolai had never seen Ilagin, but, as usual, knowing no middle way in his opinions and feelings, judging by the rumors of this landowner's violence and willfulness, hated him with all his heart and considered him his bitterest enemy" (Tolstoi, 1962a: 285).

In general, the excessiveness of Tolstoy's heroes or their inability to overcome the limits of one's own nature become an important indicator, a marker that determines the author's attitude to the character, and the situation when a hero with special, extraordinary mental powers shows evenness is always fateful.

\section{Conclusion}

Thus, the extreme points of our typology, on the one hand, are impersonal characters (Alekseev, Ayanov, in a special way impersonal Karataev in the sense of impersonality as a fusion with the people, rooted in the people's environment); and on the other hand, excessive characters, in which one (Raisky's imagination) or several (Natasha) features are developed excessively, this determines their behaviour, life strategies, and therefore their experience is often tragic.

In the area between, i.e. according to Davydov, in the mediation zone, there appears to be the "mediocre" hero with the features of evenness, calmness and moderation, calculated movements and actions, emotional balance. But inside the group he is heterogeneous. This is actually a "mediocre", severely limited hero, who risks becoming impersonal, but still is gifted spiritually. And the hero is "mediocre", but overcoming his mediocrity, limitedness in the situation of love or war, thus in part getting close to the excessive hero.

For comparison of the images of Oblomov and Raskolnikov: S.I. Ketchian "Dostoevskij's Linguistically-Based Ideational Polemic With Gončarov Through Raskol'nikov and Oblomov" (2002).

\section{References}

Belinskii, V.G. (1955). Polnoe sobranie sochinenii [The full composition of writings], Vol. 7. Moscow, 740 p.

Bulanov, A.M. (1992). "Um" $i$ "serdtse" v russkoi klassike: sootnoshenie emotsional'nogo I ratsional'nogo vtvorchestve I.A. Goncharova, F.M. Dostoevskogo, L.N. Tolstogo ["Mind" and "heart" in the Russian classics: The ratio of the emotional and rational in the works of Ivan Goncharov, Fyodor Dostoevsky, Leo Tolstoy]. Saratov, Izdatel'stvo Saratovskogo universiteta, $160 \mathrm{p}$.

Davydov, A.P. (2001). "Dukhovnoi zhazhdoiu tomim": A.S. Pushkin I stanovlenie "sredinnoi" kul'tury v Rossii ["Tormented by spiritual thirst": A.S. Pushkin and the formation of "median" culture in Russia]. Novosibirsk, Sibirskii khronograf, 244 p.

Druzhinin, A.V. (1983). "Oblomov". Roman I.A. Goncharova [“Oblomov". The novel by Ivan Goncharov]. In Druzhinin, A.V.Literaturnaia kritika [Literary criticism]. 290-313.

Dvigubski, A. (2016). Sonja's Lie: Tolstoj’s Marginal Woman Takes on a Career. In Russian Literature, 81, 49-65.

Faustov A.A. (1990). Roman I.A. Goncharova "Oblomov": khudozhestvennaia struktura I kontseptsiia cheloveka [The novel by Ivan Goncharov "Oblomov": the artistic structure and the concept of a man]. Tartu, $18 \mathrm{p}$. 
Goncharov, I.A. (1980). Sobranie sochinenii [The composition of writings]. Vol. 8. Moscow, Khudozhestvennaia literatura, $560 \mathrm{p}$.

Goncharov, I.A. (1997). Polnoe sobranie sochinenii I pisem [The full composition of writings and letters], Vol. 1. Sankt-Peterburg, Nauka, 832 p.

Goncharov, I.A. (1998). Polnoe sobranie sochinenii I pisem [The full composition of writings and letters], Vol. 4. Sankt-Peterburg, Nauka, 496 p.

Goncharov, I.A. (2003). Polnoe sobranie sochinenii I pisem [The full composition of writings and letters], Vol. 5. Sankt-Peterburg, Nauka, 496 p.

Goncharov, I.A. (2004). Polnoe sobranie sochinenii I pisem [The full composition of writings and letters], Vol. 7. Sankt-Peterburg, Nauka, 704 p.

Kadmin, N. (1913). I. Goncharov. Zhizn', lichnost', tvorchestvo [I. Goncharov. The life, the personality, the creation]. Moscow, Izdanie br. Bashmakovykh, $72 \mathrm{p}$.

Ketchian, S.I. (2002). Dostoevskij's Linguistically-Based Ideational Polemic with Gončarov Through Raskol'nikov and Oblomov. In Russian Literature, 51(4), 403-419.

Kotel'nikov, V.A. (1987). Kto takoi Oblomov? [Who is Oblomov?]. In Detskaia literatura [Children's literature], 7, 25-30.

Krasnoshchekova, E.A. (1997). Ivan Aleksandrovich Goncharov: Mir tvorchestva [Ivan Aleksandrovich Goncharov: The world of creativity]. Sankt-Peterburg, Pushkinskii fond, 444 p.

Krivolapov, V.N. (1994). Eshche raz ob "oblomovshchine" [Once more about "oblomovshchina"]. In Russian literature, 2, 27-47.

Markovich, V.M. (1975). Chelovek v romanakh I.S. Turgeneva [The man in the novels of Ivan Turgenev]. Leningrad, Izdatel'stvo Leningradskogo universiteta, $154 \mathrm{p}$.

Mashinskii, S. (1972). Goncharov I ego tvorchestvo [Goncharov and his creation]. In Goncharov I.A. Sobranie sochinenii [The composition of writings]. Vol. 1. Moscow, Pravda, 3-54.

Nedzvetskii, V.A. (1992). I.A. Goncharov-romanist I khudozhnik [I.A. Goncharov-the writer and the artist]. Moscow, Izdatel'stvo Moskovskogo universiteta, $176 \mathrm{p}$.

Pokrovskii, V.N. (1907). I.A. Goncharov. Ego zhizn' I sochineniia [Ivan Goncharov. His life and works], $332 \mathrm{p}$.

Prutskov, N.I. (1962). Masterstvo Goncharova-romanista [Skill of Goncharov-novelist]. MoscowLeningrad, Izdatel'stvo Akademii nauk USSR, 234 p.

Roman "Oblomov" v russkoi kritike [The novel "Oblomov" in Russian critics] (1991). Leningrad, Izdatel'stvo Leningradskogo universiteta, $304 \mathrm{p}$.

Shevchugova, E.I. (2013). The Image of the Mother in the Novel Trilogy by I.A. Goncharov: Typology and Functions. In Journal of Siberian Federal University. Humanities \& Social Sciences, 4(6), 616-621.

Tolstoi, L.N. (1961). Sobranie sochinenii [The composition of writings]. Vol. 4. Moscow, Khudozhestvennaia literatura, $402 \mathrm{p}$.

Tolstoi, L.N. (1962a). Sobranie sochinenii [The composition of writings]. Vol. 5. Moscow, Khudozhestvennaia literatura, $416 \mathrm{p}$.

Tolstoi, L.N. (1961b). Sobranie sochinenii [The composition of writings]. Vol. 6. Moscow, Khudozhestvennaia literatura, $448 \mathrm{p}$.

Tolstoi, L.N. (1963). Sobranie sochinenii [The composition of writings]. Vol. 7. Moscow, Khudozhestvennaia literatura, $496 \mathrm{p}$. 


\section{Интерпретация «срединного» героя}

\section{в романах И.А. Гончарова и Л.Н. Толстого}

\section{Е.И.Шевчугова}

Сибирский федеральный университет Россия, 660041, Красноярск, пр. Свободный, 79

Статья посвящена выявлению и характеристике «срединного» героя в романной трилогии И.А. Гончарова и романе-эпопее Л.Н. Толстого «Война и мир». Метод исследования - типологический. Теоретической основой работы стали изыскания В.М. Марковича и А.П. Давыдова. В изучаемых произведениях формируется сходная типология героев. Крайними точками представляются тип безличных персонажей (которые не имеют никаких выдаюшихся черт: Алексеев, Аянов, Каратаев) и тип чрезмерных героев (у них одно или несколько качеств развитьл чрезмерно: Райский, Наташа, Андрей Болконский). В зоне медиаиии находится «срединньий» герой-особый тип личности, характеризующийся ровностью, спокойствием, умеренностью в проявлении эмочий, сдержанностью поступков. Но «срединный» герой Гончарова способен преодолеть границы своего типа, эпизодически выходя за предель привычного уровня чувствования (Штольи, Ольга Ильинская, Обломов, Тушин), что не свойственно «срединному» герою Толстого (Николай Ростов).

Ключевые слова: Иван Гончаров, Лев Толстой, медиачия, типология героев, «срединный» герой.

Научная спеииальность: 10.00.00 - филологические науки. 